\title{
Project Risk Management Methodology in Practice
}

\author{
Ciril Kafol \\ Telekom Slovenije d.d., Cigaletova 15, SI-1000 Ljubljana, Republic of Sloevnia
}

\begin{abstract}
In this paper we analyze different project management approaches from the risk management point of view. Following the observed approaches, easy-to use method for risk management is developed and put into use in actual company. Procedures and methods for evaluating and managing risks are developed. Following the study of the results, easy-touse risk management method is proposed to upgrade current project management approaches. This method is usable within all project management methodologies. Using this method company managed to improve the efficiency of project management and raise the awareness of defined risks.
\end{abstract}

Keyword: project risk; risk management; risk monitoring; project management; methodology
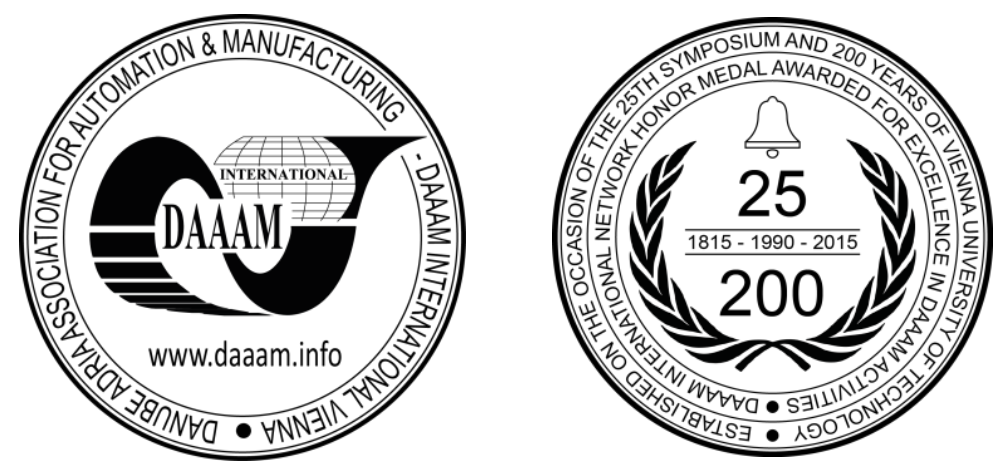

This Publication has to be referred as: Kafol, C[iril] (2016). Project Risk Management Methodology in Practice, Proceedings of the 26th DAAAM International Symposium, pp.0445-0452, B. Katalinic (Ed.), Published by DAAAM International, ISBN 978-3-902734-07-5, ISSN 1726-9679, Vienna, Austria DOI:10.2507/26th.daaam.proceedings.059 


\section{Introduction}

Project management has not been considered as area of main stream scientific research until recently therefore there is lack of scientific research in the area. Rodney Turner came to the above mentioned conclusion in which he described in this manner the scientific and research framework for the management of projects since its inception as a scientific discipline [17], as of the first decade of this century.

For the purpose of this study we have compared several main stream project management methods from the risk management point of view. The main question was if currently used project management methods use risk management tools to manage the project risks. We have researched if there is unified approach to risk management on projects. Several project management methodologies have been studied within this research (LFA, PMI, IPMA and PM4NGO) and it has been noted that there is a lack of accenting the importance of the risk management to better the project outcome. The objectives of the project define certain tasks, given that these targets are associated with the outcome, deadlines, resources and costs, at the same time represent the result of an agreement between the project owner and the project team [3].

Lalic defines organizational readiness as a measure of intelligence in a company in respect of readiness for change, survival, growth and development. It represents a criterion for evaluating intelligence business performance [13]. We consider the ability of organisation to manage risks as another factor of organisational readiness.

Some studies explore the use of risk management approaches in production process. Practice shows that risk management falls into the arena of project planning [16]. While this is approach developed for production oriented organisations, we will propose method that can be used for all types of organisations.

Risk management represents traditionally analytical approach which was established in the framework of project management [12]. It is essential that organisations develop easy-to-use pragmatic approach to handling projects in the risky environment. The key success factor to ensure desired project outcome is introducing risk management methodology into project management. Those organizations which are not successful with risk management do not provide enough time for examining the field of risk but rather leave their future in the hands of destiny [1].

In the study of Kostelac et al authors concludes that projects have a bad reputation - the odds of success are usually not good [10]. New project management methods need to be developed in order to increase odds of success. The question we will address is if easy to use and effective risk management methodology can be developed to increase the awareness of risk and better project results.

In the paper we first make a research of different project management methods and conclude that there is lack of simple, easy to use methodology suitable for all project management concepts. Then, we introduce risk management concept and develop methodology. We put methodology into practical use, introducing Risk Management Procedure into company processes. Estimating the first results we may observe raised awareness of the risks and improvement in project outcomes.

The purpose of this paper is to propose improved effective project management methodology by introducing risk management principles.

\section{Project management methods}

In the seventies, researches in the field of project management were performed by practitioners without closer ties with academic communities who then set the agenda and style of research. A decade later, the eighties were dominated by union of professionals that felt the need to form a body of knowledge as a basis for informal system titles in the field of project management. In the present period of development, project management was significantly directed toward practice, in which the result has been the emergence of a number of practice generated content [15]:

- Determination and clear principle in formulating phenomena and observations was not recognizable since the research was not based on generally accepted methodologies,

- Foothold in the literature did not exist, quotes were rare,

- Dominant carrier of information for professionals were case studies that were based on generally accepted scientific methodology,

- All records that were used for the circulation of knowledge in the field of project management were very narrow, aimed at promoting a functionality or process.

Turner also said that in the last twenty years, substantial progress was created when it comes to the quality and determination of attitudes identified in the course of research in the field of project management as documented by the author [17]:

- The number of magazines thematically related to management of projects significantly increased, ranked in different databases of scientific resources and citations of published articles, which indicates that researchbased methodology is based on generating theoretical foundation,

- Appearance of citations to a significant extent in magazines that do not belong exclusively to thematic areas of project management, which shows that the scientific studying project management achieves a significant impact on a wide range of other disciplines, 
- The possibility of identifying quotations from thematic work in other works outside areas of interest, which shows that research in the field of project management is appreciated outside the field,

- The topic of the articles include more areas of knowledge and process groups analyzing the different tools and techniques available to researchers for the successful implementation of the projects,

- Research on which articles are specifically designed using all methodologies, makes the research much more receptive and more useful in the further development of the theory.

The standards for project management are defined by the Project Management Institute - PMI and the International Project Management Association - IPMA because if there is no similarity between the projects then project management as a scientific area does not need to exist.

Kerzner considered projects as any series of tasks and activities that (1) have specific objective to be fulfilled according to the given specification, (2) have a definite beginning and ending, (3) have financial constraints, (4) they use human and other resources (For example: money, people, equipment etc.) and which (5) are multifunctional (connect multiple functions in the company) [9]. The basis for the introduction of project approach in managing organizations Jugdev and Thomas saw more than ten years ago, stating that the projects are the building blocks of business value [8].

The evolution of scientific and practical approach to project management, taking into account the significant changes in project management, according to researchers and practitioners in the course of the previous decade in 1990 brings a new wave in the art named "Emergent Project Management". Current project management methods are belonging to this stream.

Project methodology can be categorized on the basis of two variables, objectives and solutions [18].

When the target and solution (path to the target) are defined, project belongs to the category of Traditional Project Management. When the goal is defined, while the solution is not, the projects are in the category of Agile Project Management. When neither the aim nor the solution is not defined then the projects are in the category of Extreme Project Management (XPM).

A common problem in project management within an organization is its non-compliance with the strategic direction of the company. Cicmil points out that the project leaders must reposition the project management from the position of middle management towards the level of business philosophy so it can be supported by strategic changes within the organizations [2].

Within this article we explore risk management methodology that may help solve above issues. Risk management methodology on project was not treated as very important part of project management. However, this factor may critically influence achieving of the project goals.

Risk management was also not accented in the overview of standards for project management [5].

\begin{tabular}{|c|c|c|c|c|}
\hline $\begin{array}{l}\text { The critical success } \\
\text { factor }\end{array}$ & LFA & PMI (PMBOK) & $\begin{array}{l}\text { IPMA } \\
(\mathrm{NCB})\end{array}$ & PM4NGOs \\
\hline \multirow[t]{2}{*}{$\begin{array}{l}\text { Time Management } \\
\text { Plan }\end{array}$} & Not applicable & $\begin{array}{l}\text { Chapter } 6 \text { - } \\
\text { Project Time } \\
\text { Management }\end{array}$ & $\begin{array}{l}\text { Technical } \\
\text { competence: }\end{array}$ & $\begin{array}{l}\text { Technical Competence: } \\
\text { Organize a schedule so as to } \\
\text { ensure the separation and } \\
\text { the completion of work on } \\
\text { time and on budget. }\end{array}$ \\
\hline & & & $\begin{array}{l}\text { 1.11. project } \\
\text { time and } \\
\text { phase }\end{array}$ & \\
\hline $\begin{array}{l}\text { Budget } \\
\text { management }\end{array}$ & Not applicable & $\begin{array}{l}\text { Chapter } 7 \text { - } \\
\text { Project Cost } \\
\text { Management }\end{array}$ & $\begin{array}{l}\text { Technical } \\
\text { competence: } \\
1.13 \text { costs } \\
\text { and findings }\end{array}$ & $\begin{array}{l}\text { Technical Competence: } \\
\text { Organize a schedule so as to } \\
\text { ensure the separation and } \\
\text { the completion of work on } \\
\text { time and on budget. }\end{array}$ \\
\hline
\end{tabular}

Activities,

outputs,

outcomes and Quality objectives are

management defined, as well as indicators and
Chapter 5 -

Managing the project scope
Technical competence:
Technical competence: to ensure that outputs are acceptable quality

verification 


\begin{tabular}{|c|c|c|c|c|}
\hline & & $\begin{array}{l}\text { Chapter } 8 \text { - } \\
\text { Quality } \\
\text { Management } \\
\text { Project }\end{array}$ & $\begin{array}{l}\text { 1.5 Quality; } \\
\text { 1.10. The } \\
\text { scope and } \\
\text { deliverable }\end{array}$ & $\begin{array}{l}2.3 \text { Project planning: the } \\
\text { use of a WBS to define the } \\
\text { scope of project }\end{array}$ \\
\hline $\begin{array}{l}\text { The quality of } \\
\text { project } \\
\text { management }\end{array}$ & Not applicable & $\begin{array}{l}8.1 .3 .4 . \\
\text { Improvement } \\
\text { Plan process }\end{array}$ & $\begin{array}{l}\text { Technical } \\
\text { competence: } \\
1.5 \text { quality }\end{array}$ & $\begin{array}{l}\text { Page } 5 \text { necessary for high } \\
\text { quality and comprehensive } \\
\text { practice of project } \\
\text { management }\end{array}$ \\
\hline \multirow{3}{*}{$\begin{array}{l}\text { Satisfaction of } \\
\text { stakeholders/clients }\end{array}$} & \multirow{3}{*}{ Not applicable } & $\begin{array}{l}10.1 \\
\text { Identification of } \\
10.4 \text { Management } \\
\text { with the } \\
\text { stakeholders' } \\
\text { expectations }\end{array}$ & $\begin{array}{l}\text { Technical } \\
\text { competence: } \\
1.02 \\
\text { Interested } \\
\text { parties }\end{array}$ & $\begin{array}{l}\text { 2.1. Identification and } \\
\text { design of the project; } \\
\text { Need for defining } \\
\text { (identification of project } \\
\text { ideas). }\end{array}$ \\
\hline & & & & $\begin{array}{l}\text { There is a part called } \\
\text { "analyze of stakeholders" }\end{array}$ \\
\hline & & & & $\begin{array}{l}\text { But lefts out the final } \\
\text { project results for the } \\
\text { beneficiaries - Venn } \\
\text { diagrams, matrix for } \\
\text { analyzing stakeholders } \\
\text { 2.4. Implementation of } \\
\text { project; communication } \\
\text { management }\end{array}$ \\
\hline \multirow[t]{2}{*}{$\begin{array}{l}\text { Support for the top } \\
\text { management }\end{array}$} & \multirow{2}{*}{$\begin{array}{l}\text { Most of the } \\
\text { objectives are in } \\
\text { accordance with } \\
\text { the strategic } \\
\text { direction of the } \\
\text { top management }\end{array}$} & Not applicable & $\begin{array}{l}\text { Contextual } \\
\text { competitions: }\end{array}$ & Not applicable \\
\hline & & & $\begin{array}{l}3.05 . \\
\text { Constant } \\
\text { organization }\end{array}$ & \\
\hline
\end{tabular}

Table 1. Overview of standards for project management [5]

In order to improve project management efficiency it is essential to include risk management procedure into project.

\section{Introduction of project risk management}

Risk monitoring and control is the process of keeping track of the identified risks, monitoring residual risks and identifying new risks, ensuring the execution of risk plans and evaluating their effectiveness in reducing risk [12]. Current project management methods fail to accent the importance of the risk management. Risk may be a deciding factor in project success therefore it is necessary to monitor and manage it. The uncertain global environment leaves time and risk as an opportunity [12].For this purpose the following methodology was developed and implemented.

Risk Management process is consisted of the following sub-processes [7]:

- $\quad$ Risk Identification

- $\quad$ Risk Assessment

- $\quad$ Risk Response

- $\quad$ Risk Monitoring and

- $\quad$ Risk Reporting

In the identification process, following this approach the organization shall define the consequences of certain action and define probability of the action. Based on this calculation of the risk level shall be done. As the last step risk response shall be defines in order to define organization way to handle identified risks. Risks shall be monitored, communicated and reported on regular basis. It is very important that all phases of risk management process are respected in order to provide organization and/or project manager with the in-depth understanding of the risk portfolio. Presence of clear and concise procedures will enable organization to be aware of the risk structure on all levels. 


\subsection{Definition of consequences}

The possible outcomes of an event are considered the consequences of risks. These consequences can be positive or negative, and are assessed with regard to achieving established objectives. A points system is used in order to categorize risk according to predefined criteria (Table 2) [7].

\begin{tabular}{lll}
\hline Points & Significance & Criteria \\
\hline 4 & Very significant & $\begin{array}{l}\text { Financial effect will be more than } 2,5 \% \text { of the company revenues, } \\
\text { mission and core activities threatened, legal, project failure }\end{array}$ \\
\hline 3 & Significant & $\begin{array}{l}\text { Financial effect will be between } 0,5 \text { and } 2,5 \% \text { of operating revenues, } \\
\text { changes of plans and organization required, customer satisfaction }\end{array}$ \\
\hline 1 & Moderate & $\begin{array}{l}\text { Financial effect between } 0,05 \text { and } 0,25 \% \text { of the company revenue, } \\
\text { activities need to change, reputation damage, project changes }\end{array}$ \\
\hline Minor & $\begin{array}{l}\text { Financial effect less that } 0,05 \% \text { of the operating revenues, } \\
\text { Implementation not threatened }\end{array}$ \\
\hline
\end{tabular}

Table 2. Definition of consequences point system

The criteria for assessing the consequences of risks (at the company level) are broken down into the following two groups [7]:

1. The significance (principle of materiality) of the consequence on operations,

2. Sensitivity of the area.

\subsection{Definition of probability}

The question that we should answer is: How likely is it that a certain event will occur, and how frequently? Criteria for assessing are listed in Table 3.

\begin{tabular}{lll}
\hline Points & Assessment & Criteria \\
\hline 4 & Almost certain & Probability above $75 \%$ \\
3 & High probability & Probability between 50 and $75 \%$ \\
2 & Possible & Probability between 25 and $50 \%$ \\
1 & Low probability & Probability less than $25 \%$
\end{tabular}

Table 3. Criteria for assessing the probability of occurrence of a negative event or the loss of an opportunity

\subsection{Calculation of the risk level (seriousness of risk)}

The seriousness of a risk is calculated as the product of the consequences and probability of a risk. The formula used is Error! Reference source not found.:

$$
\text { Risk }=\text { consequence } \mathrm{x} \text { probability }
$$

Risk equals consequence multiplied by probability.

We assess inherent risk without taking into account the impact of possible additional measures to reduce risk, as well as the residual risk to which we are actually exposed, taking into account the impact of activities to reduce risk Error! Reference source not found. 
The significance of a risk is illustrated using the risk matrix below (Figure 1).

\begin{tabular}{ccccc} 
Impact & \multicolumn{1}{c}{} & \\
\hline $\begin{array}{c}\text { Very } \\
\text { significant }\end{array}$ & $\mathbf{4}$ & $\mathbf{8}$ & $\mathbf{1 2}$ & $\mathbf{1 6}$ \\
\hline Significant & $\mathbf{3}$ & $\mathbf{6}$ & $\mathbf{9}$ & $\mathbf{1 2}$ \\
\hline Moderate & $\mathbf{2}$ & $\mathbf{4}$ & $\mathbf{6}$ & $\mathbf{8}$ \\
\hline Minor & $\mathbf{1}$ & $\mathbf{2}$ & $\mathbf{3}$ & Almost certain
\end{tabular}

Fig. 1. Risk matrix

White areas represent low risk with points 1 to 3. Light grey areas represent medium risk with points 4 to 6 . Dark grey areas represent high risk with points from 8 to 9 . Black areas represent very high risk with points from 12 to 16.

\subsection{Risk response}

Priorities are set with regard to the risk assessments performed and the weighing of costs and benefits (principle of prudent management) [7]. The most appropriate risk response, which will ensure the desired level of risk exposure following the implementation of measures, is selected. We have developed easy-to-use method for managing risks, comprising out of three possible responses to risk as described in further text.

Risks are managed using the following methods:

a) Avoiding risk - discontinuation of risky operations.

b) Mitigation (reducing) risk - the use of different safety measures, such as: establishing scenarios for reducing risk to an acceptable level and establishing internal controls. Transferring risk to a third party - i.e. using insurance via an insurance company, outsourcing, etc.

c) Accepting risk - accepting a risk that is acceptable or in line with management policies regarding risk appetite. Furthermore, observed organization introduced risk assessment procedure as a part of project management practice in order to monitor and manage risks. Every organization should develop its own procedure to follow risks depending on specifics of the business and industry. There are numerous possibilities how to monitor risks. The key success factor of the methodology is commitment of the organisation to understand the benefits of such procedure. It is crucial that the top management is committed to the project. Regular reporting to top management is therefore obligatory. Executive summary shall summarize risk data from all projects. Bellow (Figure 2) is the example of the Risk Assessment procedure that is embedded into project procedure and approval procedure in observed company. It ensures that all project managers shall fulfil the basic risk assessment sheet and is aligned with existing approval procedure for projects. By being a part of approval procedure it creates awareness of the top management.

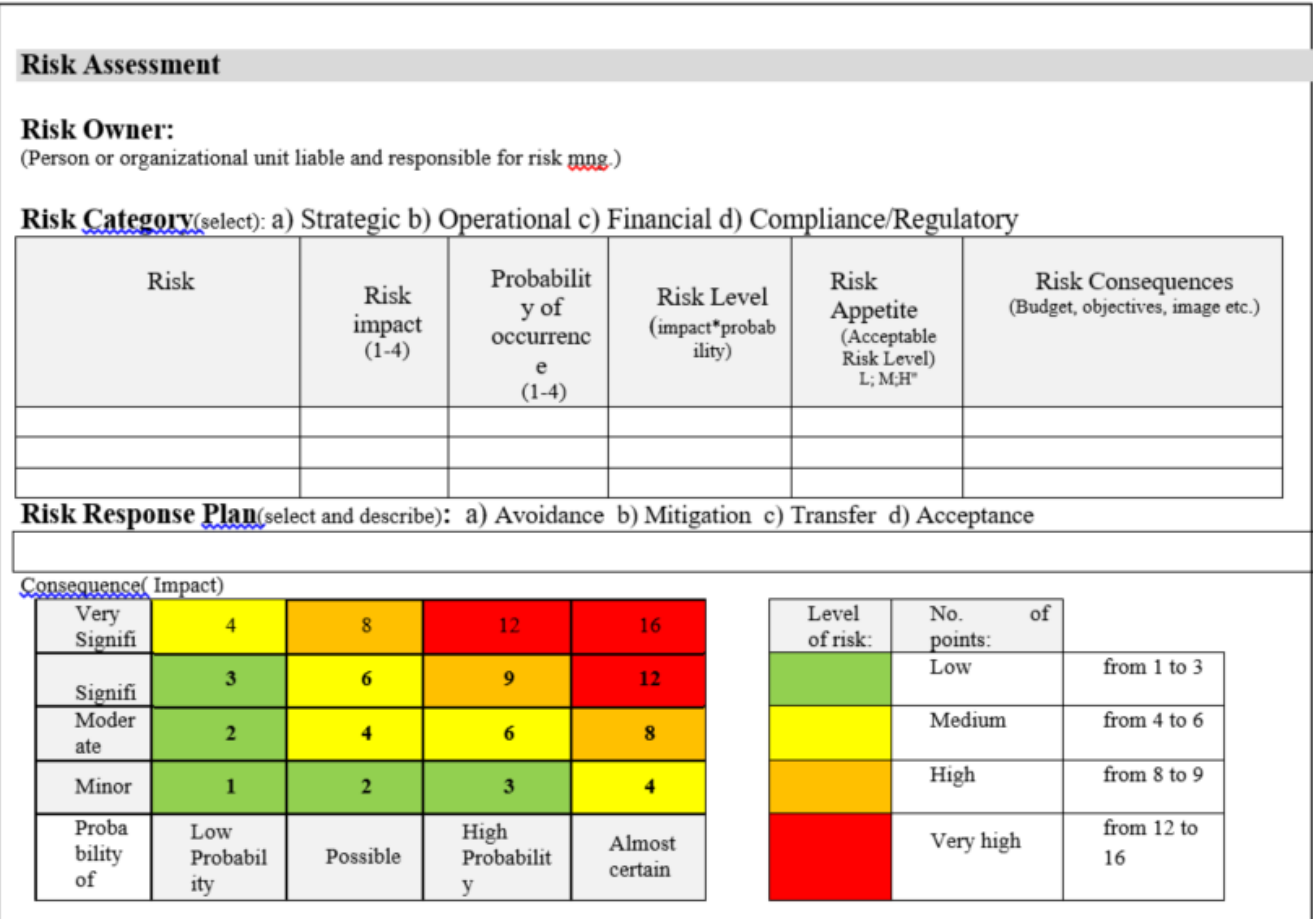

Fig. 2. Example of Risk Assesment procedure 
Above figure was developed for the purpose of managing risks within project management practice in small sized telecommunication operator located in small CEE country. It was used for the period of 2 years, after which the assessment was performed. The assessment showed positive influence on project management procedure and, as a part of overall risk management practice in the Group, gave comprehensive picture of the risk.

\section{Conclusion}

We have developed new easy-to-use method of managing risk on projects. Processes and elements of risk management include: risk, risk events, risk planning, risk assessment, risk handling, risk monitoring and risk documenting [1]. The method was based on risk management as an organized method for identifying and measuring risk and for selecting, developing and implementing options for handling of the risks [11]. Being a part of project management procedure manager and team members are becoming aware of the risks and in the process of planning, risk response strategies are developed in order to mitigate risk. We propose this approach which can enable management at all levels to monitor and manage risks. This method was tested in practice and it shows that raising risk awareness gives and important information to project managers enabling them to minimize uncertainty for achieving project results thus bettering the project outcome.

Risk is not a problem. It is the perception of the level of danger according to the possible troubles [11]. The fact is that we operate in volatile and risky environments. It is a part of normal business operations and organisation and project managers should not underestimate the importance of managing risks. This risk management procedure is applicable in all project management methodologies and judging by results achieved in a company, improves efficiency in operational project handling. Methodology was tested in operation in the company in the field of telecommunications. It became a part of standard operational procedure for project management, project risks were discussed and managed, project management practice improved. Risk management methodology should be introduced as critical success factor into existing project management standards.

Further research is conducted in order to define and quantify the influence of using risk management methodology on element of project outcome. The research will be conducted in order to further improve the methodology.

\section{References}

[1] Buchmeister, B.; Pandza, K.; Kremljak, Z. \& Polajnar, A. (2004). Possibilities of practical use of risk management, Proceedings of 3rd International scientific conference Business systems management, University of Mostar

[2] Cicmil, S. (1997). Critical factors of effective project management. The TQM Magazine , 390-396.

[3] Gareis, R. (2002). PM Baseline (english version): 1.0. Vienna: Projekt Management,Austria.

[4] Grey, S. (1995). Practical Risk Assessment for Project Management, John Wiley \& Sons, Chicester

[5] Hermano, V., Lopez-Paredes, A., Martin-Cruz, N., \& Pajares, J. (2012). How to manage international development (ID) projects successfully. Is the PMD Pro1 Guide going to the right direction? International Journal of Project Management, 31 (2013) 22-30.

[6] Holmes, A. (2002). Risk management, Capstone Publishing, Oxford Publishing, Vienna

[7] Internal company document EQPIA.038 Risk Management Procedure (2014), several authors, not published

[8] Jugdev, K., \& Thomas, J. (2002). Project management maturity models: The silver bullets of competitive advantage. Project Management Journal , 33 (4), 4-14.

[9] Kerzner, H. (2006). Project Management. Hoboken: John Wiley \& Sons.

[10] KOSTELAC, D[razen]; MATRLJAN, D[amir] \& DOBOVICEK, S[andro] (2011): Relationship between processes and project management, Annals of DAAAM for 2011 \& Proceedings of the 22nd International DAAAM Symposium, Volume 22, No. 1, ISSN 1726-9679, ISBN 978-3-901509-83-4, Editor B. Katalinic, Published by DAAAM International, Vienna, Austria, EU, 2011

[11] Kremljak Z. (2011): Risk management methods-Project risk, Chapter 10 in International Scientific Book 2011 pp119-132, B.Katalinic (Ed.), Published by DAAAM International, ISBN 978-3-901509-84, ISSN 1726-9687, Turner R (2009), The handbook of Project Based Management, New York, McGraw Hill, Vienna Austria Operationa Research Vol 116, 436-442

[12] Kremljak, Z[vonko] \& Kafol, C[iril] (2012). Options, Uncertainty and Capability Development, Chapter 07 in DAAAMInternational Scientific Book 2012, pp. 075-086, B. Katalinic (Ed.), Published byDAAAM International, ISBN 978-3-901509-86-5, ISSN 1726-9687, Vienna, Austria DOI: 10.2507/daaam.scibook.2012.

[13] Lalić, B., \& Marjanović, U. (2011). Level of preparedness of SMEs. In M. M. Cruz-Cunha, \& J. Varajão, EBusiness Issues, Challenges and Opportunities for SMEs: Driving Competitiveness. Lisbon, Portugal: IGI Global Publisher

[14] Milosevic, D., \& Srivannaboon, S. (2006). Theoretical framework for aligning project management with business strategy. Project Management Journal , Vol. 37, No, 3.98-110.

[15] Stake, R. E. (2008). The Case Study Method in Social Enquiry, 7(2), 5-8. 
[16] SUSTEROVA, M[onika]; LAVIN, J[aak] \& RIIVES, J[ueri] (2012) : Risk management in product development process, Annals of DAAAM for 2012 \& Proceedings of the 23rd International DAAAM Symposium, Volume 23, No.1, ISSN 2304-1382, ISBN 978-3-901509-91-9, Ed. B. Katalinic, Published by DAAAM International, Vienna, Austria, EU, 2012

[17] Turner, R. (2010). Evolution of project management research as evidenced by papers published in the International Journal of Project Management. International Journal of Project Management , 1-6.

[18. Wysocki, R. (2009). Effective Project Management. Indianapolis: Wiley Publishing. 